\title{
EXPLORING THE LINK BETWEEN FOREIGN LANGUAGE ANXIETY AND ATTITUDES TOWARDS ENGLISH AMONG TURKISH HIGH SCHOOL EFL LEARNERS
}

\author{
Zekiye Özer ${ }^{1}$ \\ Niğde Ömer Halisdemir University, Turkey \\ Ramazan Yetkin \\ Hacettepe University, Turkey
}

\begin{abstract}
The current study was conducted to investigate the relationship between foreign language anxiety (FLA) and attitudes towards English. A total 518 Turkish students studying at private and state high schools participated in the study. Quantitative research design was adopted in the present study. Foreign Language Classroom Anxiety Scale (FLCAS) and Attitudes towards English Scale (ATES) were used as data collection tools. In order to analyze data, SPSS 23 software was used, and Multivariate Analysis of Variance (MANOVA) and correlation statistics were utilized. According to data analysis results, the study revealed that students' FLA levels were moderate, and they had negative attitudes towards English. The results also indicated that there was a negative strong relationship between students' FLA levels and their attitudes towards English. Although gender had a significant impact on students' anxiety levels, grade levels of students were not seen as a factor strongly related to FLA. It was also found that ninth and tenth graders had more positive attitudes towards English classes. However, gender was not a predictive factor for students' attitudes towards English. These results suggest that positive attitudes help students to overcome FLA. That is why, fostering positive and enjoyable language learning environment is significant to increase success in English.
\end{abstract}

Keywords: foreign language anxiety, attitude, high school students, grade level, gender.

\section{Introduction}

In the new global world, learning a foreign language has become a central issue to contact with humankind from all over the world. For this reason, investigating new techniques to improve the quality of language education is an ongoing concern not only for individuals but also for governments trying to solve the problems in foreign language

${ }^{1}$ Correspondence: zekiyeozer19@gmail.com 
education (Oktay, 2015; Unal \& Ilhan, 2017). That is why, following the latest developments and studies related to language education plays a critical function in the maintenance of achievement in learning a foreign language.

Evidence suggest that personal differences play a key role in language learning process because those differences define the success levels in language skills (Dörnyei \& Ryan, 2015), and therefore, individual differences have become an object of research in field of language education. Apart from the cognitive variables, there has been renewed interest in the importance of affective variables in language learning process (Arnold, $2011 ; \mathrm{Ni}, 2012)$. Anxiety is one of the most widely studied affective factors in language education. A large and growing body of literature has investigated FLA and its relationship with various determinants like motivation, beliefs related to language learning, personality, and achievement as well (Aida, 1994; Horwitz, 1986; Hussain et al., 2011). However, there is still an uncertainty on whether attitudes towards English predict the anxiety levels of language learners. Since attitude is considered as one of the significant determinants in foreign language learning, the effect of attitudes on FLA should be investigated. For this reason, this study is conducted to explore the influence of attitudes towards English on language anxiety. It also examines gender and grade levels' effect on students' anxiety level.

\section{Literature Review}

A considerable amount of literature has been published to describe the role of anxiety in language learning process (Coşkun \& Taşgin, 2018; Horwitz et al., 1986; MacIntyre \& Gardner, 1991; Tokur, 2016). It is necessary to describe what is meant by the word 'anxiety'. There are multiple definitions of anxiety; however, in broad terms, it can be defined as "the subjective feelings of tension, apprehension, nervousness, and worry associated with an arousal of the autonomic nervous system" (Spielberger, 1983; p. 15).

MacIntyre and Gardner (1991) described three basic kinds of anxiety: "trait anxiety, state anxiety, and situation-specific anxiety". In the literature, trait anxiety is generally understood to mean "a feature of an individual's personality and therefore is both stable over time and applicable to wide range of situations" (MacIntyre, 1999, p.2 17). The term 'state anxiety' tends to be used to refer to "varies in intensity and duration and fluctuates over time as a function of the amount of stress that impinges upon an individual and that individual's interpretation of the stressful situation as personally dangerous or threatening" (Spielberger, 1976, p. 5). Situation-specific anxiety is a more recent term and Chan and $\mathrm{Wu}$ comment on that "unlike trait and state perspective, situation-specific perspective requires the respondents to ascribe their anxiety to particular sources." (2004, p.291).

One of the most significant discussions in anxiety is whether it has positive or negative effect on peoples' lives. That is why, researchers draw a distinction between "facilitating anxiety" and "debilitating anxiety". According to a definitions provided in the literature, while facilitating anxiety regulate individual's performance in a positive and motivate them to accomplish, debilitating anxiety has detrimental effect on people and it leads to avoidance behavior during the task performance (Alpert \& Haber, 1960).

The concept FLA was introduced by Horwitz et al. (1986) as "a distinct complex of self-perceptions, beliefs, feelings, and behaviors related to classroom language learning that arise from the uniqueness of the foreign language learning process" (p. 128). As previously stated, the issue of anxiety and its impact on learning process has been a controversial topic within the field of language education due to the inconsistent research results. Horwitz et al. (1986) developed the FLCAS to avoid inconsistency among the researchers by providing them a standard instrument. Historically, research investigating the factors associated with FLA has focused on learner differences, teachers, peers, and classroom environment. Numerous studies have attempted to explain the influence of 
FLA on the learners' foreign language performance and their results revealed that FLA and achievement were negatively correlated (Aida, 1994; Horwitz, 1986; Kunt, 1997; MacIntyre \& Gardner, 1991).

On the question of the relationship between anxiety and gender, literature offers contradictory findings. Numerous studies indicated that gender is a determining factor in FLA among students. Some researchers point out females feel high level anxiety (Aydin, 2008; Dewaele et al., 2008; Öztürk \& Gürbüz, 2013). However, others claim that males are more anxious compared to females while learning a foreign language (Aida,1994; Campbell \& Shaw, 1994; Na, 2007; Wang, 2014). To date, several studies have investigated whether students grade levels have a significant effect on their FLA (Dewaele et al., 2008; MacIntyre \& Gardner, 1994). Those studies provide contradictory results. In their seminal article, Dewaele et al. (2008) note that younger students are more anxious. However, MacIntyre and Gardner (1994) report that older students have high level of anxiety.

As deduced from the inconsistent results stated above, the impact of gender and grade level on FLA is confusing; that is why, there is a need to conduct more comprehensive studies to understand their relationship. Apart from those variables, a considerable literature has focused on the link between FLA and attitudes towards English. When students feel anxious during the language courses, this may affect their performances and they may gain negative attitudes towards the target language. Detailed examination of relation between anxiety and attitudes by Hussain et al. (2011) show that there is a negative link between students' anxiety levels and their attitudes. It has been noted that the students who have positive attitudes towards English experience low level of anxiety. This view is supported by Karagöl and Başbay (2018) who reveal that respondents who reported negative attitudes towards English also reported significantly high levels anxiety. To determine the connection between students FLA levels and their attitudes towards English, Pan and Akay (2015) conducted a study with university students. Unlike Hussain et al. (2011), they find out that no significant link exists between anxiety and attitudes towards English lesson. Similarly, in their study conducted with 700 university student, Coşkun and Taşgin (2018) note that there is no relationship between attitudes and anxiety.

In Türkiye, recently, educators and policy makers have shown an increased interest in language teaching field. In this regard, they developed new curriculum for English language education and fifth graders studying pre-determined project class start to attend English intensive program. Moreover, both students and their families are aware of the importance of learning a language not only for career opportunities but also to be a global citizen in rapidly changing world. Taking into account all of these, identifying learners' attitudes on English and the factors determining their achievement in their English classes is a continuing concern within field of SLA. However, it is now well established that the studies on language anxiety and factors causing anxiety yields inconsistent results. That is why, this paper investigates the determinants of FLA among high school students. This work will generate fresh insight into FLA and factors affecting the rate of anxiety. It will also provide teachers with new ideas to create an effective learning environment for their students by eliminating the causes of anxiety and helping them to develop positive attitudes towards English. In this respect, the following research questions are formulated.

1) What is the level of FLA among high school students, and their overall attitudes towards English?

2) Is there a significant difference between participants' FLA levels, and their gender and grade levels?

3) Is there a significant difference between participants' attitudes towards English, and their gender and grade levels? 
4) Is there a relationship between participants' level of anxiety and their attitude towards the English?

\section{Research Design}

The present study was conducted by applying quantitative research design and procedures. Quantitative research, as best explained by Dörnyei (2007, p. 34) "is systematic, rigorous, focused, and tightly controlled, involving precise measurement and producing reliable and replicable data that is generalizable to other contexts". Quantitative data analysis is more researcher friendly requiring less time, effort, and resource (Dörnyei \& Taguchi, 2010), and helps researcher to use the data more purposeful (Ho, 2018). In the study, combining all the aforementioned benefits, the researchers aimed at reaching as much participants as possible by using questionnaires, used quantitative data methodology so that the obtained data could be analyzed objectively and generalizable to larger population.

\section{Sample and Participants}

The current study conducted in 2017-2018 academic year. The sample of this study consists of $(\mathrm{N}=518)$ high school students studying at a state high school and a private high school in Turkey. The table below provides demographic information of the participants.

Table 1

Background of the participants

\begin{tabular}{clcc}
\hline & & Frequency $(\mathrm{f})$ & Percentage $(\%)$ \\
\hline Gender & Male & 220 & 42.5 \\
& Female & 298 & 57.5 \\
\hline Grade & 9th graders & 197 & 38.0 \\
& 10th graders & 188 & 36.3 \\
& 11th graders & 52 & 10.0 \\
& 12th graders & 81 & 15.6 \\
\hline \multirow{2}{*}{ School Type } & State school & 425 & 82.0 \\
& Private school & 93 & 18.0 \\
\hline
\end{tabular}

\section{Data Collection Tools}

A background information form, FLCAS and ATES were used with the purpose of gathering data. Background information form includes questions about participants' gender, age, grade, their school types, their purposes of learning English, and the time that they have spent to learn English.

Foreign Language Classroom Anxiety Scale (FLCAS)developed by Horwitz et al. (1986) and adapted to Turkish by Aydin et al. (2016) was administered in order to measure FLA levels of the participants. In this scale, there are 33 items in 5-point Likert-type scale from "strongly agree" to "strongly disagree". The scale had three components which are communication apprehension, test anxiety and fear of negative evaluation. In the present study, the Cronbach alpha coefficient is calculated as .94.

Attitudes towards English Scale (ATES) developed by Aiken (1979) and adapted to Turkish by Tuncer et al. (2015) was used to scrutinize the participants' attitudes towards English. It consists of a 5 point Likert- type of scale with 19 items from "strongly disagree" to "strongly agree". The scale has a four-factor structure. These factors are attitudes towards learning, personal factors, motivation, and importance of English. In the current study, Cronbach's alpha coefficient is .94. 


\section{Data Collection and Data Analysis}

The data of the existing study were collected from Turkish high school EFL students by using aforementioned questionnaires. The researchers were responsible for the delivery of the questionnaires. Before the collection phase, both principals and teachers were informed about the process. The data were collected just before each course session and accompanied by the class teacher. Necessary information about the study and the confidentially were announced to the participants and only voluntary participants were taken part in the study. Obtained large data set were entered and analyzed through SPSS 23 software program. The dispersion of the data was checked by using test of normality. An inspection of the results by looking at Kolmogrov-Smirnov test, Mean and Trimmed mean values, and Histogram and Q-Q Plot graphs indicated normal distribution of the data; therefore, parametric tests were applied for the further analyses. Participants perceived levels of FLCAS and ATES scores were calculated by using descriptive statistics. The relationship between FLCAS and ATES levels were disclosed by applying a Pearson-Product Moment Correlation analysis. In order to disclose participants grade and gender differences on their ATES and FLCAS scores, two separate sets of MANOVA were conducted.

\section{Findings}

The first set of analyses examine the level of FLA and attitudes towards English. High mean value for FLA scale means that students have high level of anxiety. For attitudes scale, high mean value suggests that students have positive attitudes toward English lesson. Table 2 illustrates that students' FLA levels $(\mathrm{M}=3.37, \mathrm{SD}=.78)$ are at the moderate level. When it comes to levels of attitudes towards English, it can be inferred that students' attitudes towards English is at low level $(\mathrm{M}=2.42, \mathrm{SD}=.82)$.

Table 2

Descriptive statistics for FLA and attitudes towards English

\begin{tabular}{llll}
\hline & $\mathrm{N}$ & Mean & SD \\
FLA & 518 & 3.37 & .78255 \\
Attitudes towards English & 518 & 2.42 & .82981 \\
\hline
\end{tabular}

In order to check the impact of gender on students' levels of FLA, a one-way MANOVA was conducted. Three components of FLA were used as dependent variables. As shown in Table 3, the results of MANOVA yield statistically significant difference between males and females on the combined dependent variables, $\mathrm{F}(3,514)=4.57$, $\mathrm{p}=.004$; Wilk's Lambda $=.98$; partial eta squared $=.02$. When the results for the dependent variables are considered separately, males and females differ in communication apprehension $\mathrm{F}(1,516)=8.27 ; \mathrm{p}=.004$; partial eta squared $=.016$ and fear of negative evaluation $\mathrm{F}(1,516)=9.59 ; \mathrm{p}=.002$; partial eta squared $=.018$. According to mean scores, males show a small scale higher levels of communication apprehension $(\mathrm{M}=3.33$, $\mathrm{SD}=.048)$ than females $(\mathrm{M}=3.15, \mathrm{SD}=.042)$. In addition, males have higher levels of fear of negative evaluation $(\mathrm{M}=3.56, \mathrm{SD}=.062)$ than females $(\mathrm{M}=3.31, \mathrm{SD}=.0 .53)$.

Table 3

$M A N O V A$ results for gender

\begin{tabular}{clllc} 
& Wilks' $\Lambda$ & $\mathrm{F}(3,514)$ & $\mathrm{p}$ & Partial eta2 \\
\hline Gender & .98 & 4.57 & .004 & .02 \\
\hline
\end{tabular}

For the purpose of checking the effect of grade levels on students' levels of FLA, a one-way MANOVA is conducted. Three components of FLA are used as dependent 
variables. There are no statistically significant differences between grade levels and dependent variables, $\mathrm{F}(3,514)=.89, \mathrm{p}=.534$; Wilk's Lambda $=.98$; partial eta squared $=.005$.

Table 4

MANOVA results for grade level

\begin{tabular}{llllc} 
& Wilks' $\Lambda$ & $\mathrm{F}(3,514)$ & $\mathrm{P}$ & Partial eta2 \\
\hline $\begin{array}{l}\text { Grade } \\
\text { level }\end{array}$ & .98 & .89 & .534 & .005 \\
\hline
\end{tabular}

With the intention of revealing gender impact on students' attitudes towards English, a one-way MANOVA is conducted. Four dependent variables are used: attitudes towards learning, personal factors, motivation, and importance of English. As table below indicates, there is no evidence that gender has an influence on dependent variables, $\mathrm{F}$ (4, $512)=.87, \mathrm{p}=.47$; Wilk's Lambda $=.99$; partial eta squared $=.007$.

Table 5

$M A N O V A$ results for gender

\begin{tabular}{clllc} 
& Wilks' $\Lambda$ & $\mathrm{F}(4,512)$ & $\mathrm{P}$ & Partial eta2 \\
\hline Gender & .99 & .87 & .47 & .007 \\
\hline
\end{tabular}

MANOVA analysis is run in order to identify grade level differences in attitudes towards English. Four components of attitudes towards English scale (attitudes towards learning, personal factors, motivation, and importance of English) are used as dependent variable. There is a statistically significant difference between ninth graders, tenth graders, eleventh graders, and twelfth graders on the combined depended variables, $\mathrm{F}$ $(3,513)=2.88, \mathrm{p}=.00$; Wilks' Lambda $=.93$; partial eta squared $=.02$. A further examination of group differences on individual depended variables reveals that the differences between grade levels are significant by using a Bonferroni adjusted alpha level .012 on attitudes towards learning, $\mathrm{F}(3,513)=5.81, \mathrm{p}=.001$; partial eta squared $=.03$, and on motivation $\mathrm{F}(3,513)=3.71, \mathrm{p}=.01$; partial eta squared $=.02$. An inspection of mean scores indicates that 10th graders have slightly more positive attitudes towards learning $(\mathrm{M}=2.61)$ than 9th graders $(\mathrm{M}=2.38)$, 12th graders $(\mathrm{M}=2.22)$ and 11 th graders $(\mathrm{M}=2.06)$. In addition, 10th graders $(\mathrm{M}=2.55)$ are more motivated to learn English than 9th graders $(\mathrm{M}=2.41)$ and 12th graders $(\mathrm{M}=2.39)$. 11th graders $(\mathrm{M}=2.07)$ are the least motivated to learn. When the results for personal factors and importance of English are considered separately, there is no statistically significant difference for grade levels.

Table 6

MANOVA results for grade level

\begin{tabular}{clllc} 
& Wilks' $\Lambda$ & $\mathrm{F}(3,513)$ & $\mathrm{P}$ & Partial eta2 \\
\hline Gender & .93 & 2.88 & .00 & .02 \\
\hline
\end{tabular}

Table 7

Correlation results

\begin{tabular}{lll}
\hline & 1 & 2 \\
\hline 1 FLA & 1 & $.61^{* *}$ \\
2 Attitude & $.61^{* *}$ & 1 \\
\hline *** Correlation is significant at the 0.01 level (Q-tailed) &
\end{tabular}

**Correlation is significant at the 0.01 level (2-tailed).

Pearson correlation coefficient was applied to explore the link between FLA and 
attitudes towards English. As it is presented in the Table 7, a strong negative correlation is found, $\mathrm{r}=-.61, \mathrm{n}=518, \mathrm{p}=.00$, with $\% 37$ variance of the coefficient of determination. This result shows that high level of anxiety linked with negative attitude towards English.

\section{Discussion}

This paper seeks to indicate the link between attitudes towards English and FLA. Regarding the first research question, Turkish high school students' anxiety is at moderate level in their language classes. The interesting finding is that students have negative attitudes towards English. This outcome is contrary to that of Pan and Akay (2015) who found students have positive attitudes towards English and also they feel high level of FLA. It might be that since students fear of hearing negative judgements by teachers and peers, they do not feel comfortable in their English classes. This fear can give rise to anxiety in classroom. As a consequence, students have negative attitudes towards English. This argument corroborates the ideas of Çoşkun and his co-author (2018), who suggested that when students feel themselves insecure in classroom, their anxiety levels increase.

In the first background information form, students indicated their purposes of studying English and the hours that they spend to study English. The results illustrated that high school students learn English mostly in order to pass their courses (22\%). Moreover, most of them (51\%) stated that they study English only for preparing their exams and they do not spend any time to learn English at their home. It seems possible that these results are due to their anxiety levels in English courses and unfavorable attitudes towards English. This finding is also reported by Tokur (2016). She confirms that a positive correlation exists between students' attitudes towards English and the time that they allocated to study English.

Another question in this research was whether gender and grade level of students affect students' FLA levels. On the question of the effect of gender, it was revealed that males feel higher level of anxiety in their English courses. This accords with data obtained in the study conducted by $\mathrm{Na}$ in 2007 with 115 Chinese EFL students. The results show that female students are less anxious than male students in their language courses. It may be that female students have higher level self-confidence than males. Moreover, females may be more motivated to learn English by bearing in mind that learning English increases the opportunity to find a job in Türkiye. Detailed examination of results indicates that the male students' level of communication apprehension and fear of negative evaluation are higher than females. It may be that these participants are worried about speaking in front of class for the fear of making mistake.

These results are partly consistent with data obtained by Wang in 2014. Wang (2014) stated that although fear of negative evaluation levels of both males and females are almost similar, communication apprehension levels of males are higher than females. A note of caution is due here since there has been little agreement on effect of gender on FLA. The most important reason is cultural differences which causes sex role stereotypes. Therefore, more cross-cultural studies should be conducted to understand the role of gender on level of anxiety. Another important finding is that grade level is not a determining factor in participants' FLA levels. This finding does not support the previous research which have suggested that a significant difference exists between younger and older learners (Dewaele et al. 2008; MacIntyre \& Gardner,1994). This outcome may partly be explained by the fact that there is not any balance in the number of participants considering their grade level. Another possible explanation is that participants' grades are in a close range and their past experiences with English is almost similar. For this reason, their attitudes do not change according to their grade levels.

The relationship between students' gender, grade levels and their attitudes 
towards English was the third question of the study. According to results, gender is not a contributory factor to students' attitudes. Regardless of their gender, high school students have negative attitudes towards English. This outcome is contrary to that of Çoskun and Taşgin (2018). They found that females have more positive attitudes towards English than males. It might be that content of English classes has the same effect on both males and females. Since all the students are attending standardized compulsory English education, their attitudes are similar to each other. However, in terms of grade level, the results yield significant difference. That is, their attitudes towards English change according to their grade levels.

When each component of attitude scale is considered, especially, attitude toward learning and motivation indicated a significant difference for each grade level. Ninth and tenth graders are more motivated, and they have more positive attitudes to learn. The reason for more positive attitudes towards learning and motivation of those students can be interpreted as they are at the beginning of high school education and that is why, they can spend more time to study English. However, eleventh and twelfth graders are preparing for university entrance exam. They may allocate less time to study English with the thought that they are not responsible for English in that exam. Consequently, they are unwilling to learn English and have negative attitudes towards the course in consideration of studying English is loss of time. However, the findings of the current study do not support the previous research conducted by Çoşkun and friend (2018). They found that freshman students are less anxious when they compared with the sophomores.

The most important intention of this paper is to explore the link between FLA levels and attitudes towards English. Correlation results demonstrate that a negative correlation exists between attitude and anxiety in English classes. It suggests that negative attitudes towards English courses is among the antecedents of anxiety. These outcomes are in agreement with those of previous studies. Thus far, several studies have confirmed the negative relationship between attitudes towards English and FLA (Karagöl \& Başbay, 2018; Hussain et al., 2011). It might be that lack of interest in learning English leads students to get bored while studying English. Moreover, they do not want to spare time to learn English because they consider it as an obligation and do not enjoy while learning English. As a consequence of these, they may have difficulty in learning English and what is worse they may fail the course. All these factors can impact on the anxiety levels of students. Therefore, in order to reduce anxiety among students, educators need to help students to maintain positive attitude towards English courses. Karagöl and Başbay (2018) stated that "if students develop a negative attitude and high anxiety levels, it becomes difficult for them to motivate themselves to learn that language" (p. 818). That is why, decreasing anxiety levels and helping students to develop positive attitudes are important to increase learners' success.

\section{Conclusions}

In this study, the aim is to discuss the link between attitudes towards English and FLA. It also presents an overview of the effects of gender and grade level on participants' anxiety levels. This study has identified that gender has a determining effect on students' levels of language anxiety. However, it is found that students' anxiety levels do not differ according to their grade levels. The major finding is that students' attitudes towards English and FLA are negatively correlated with each other.

Taken together, these results suggest that to overcome anxiety in language classroom, teachers should help students to maintain positive attitudes towards English. They need to design more interesting and enjoyable learning environments to draw students' attention to lesson. Moreover, they need to set a purpose for the activities and clearly explain the course objectives to students. By this way, students could have 
meaningful purposes to learn language, and they can gain positive attitudes towards English.

It is important to have a positive and comfortable classroom environment so that students can be aware of the fact that their mistakes will be tolerated. Classroom materials should be designed according to students' levels thus and so; students will realize that they can succeed in their English courses. When teachers encourage students and increase their motivation to learn English, students feel more confident and do not feel anxious while learning English.

Since the study is limited to items in questionnaire, a further longitudinal study would be of great help in exploring the dynamic nature of anxiety. Moreover, to better understand FLA, the determinants of anxiety should be further investigated. That's why, further research should be conducted to fully understand the FLA, and to find solutions in order to overcome anxiety.

\section{References}

Aida, Y. (1994). Examination of Horwitz, Horwitz, and Cope's construct of foreign language anxiety: The case of students of Japanese. The Modern Language Journal, 78(2), 155-168.

Aiken, Lewis R. (1979). Attitudes toward mathematics and science in Iranian middle schools. School Science and Mathematics, 79 (3), 229-234.

Alpert, R., \& Haber, R. N. (1960). Anxiety in academic achievement situations. The Journal of Abnormal and Social Psychology, 61(2), 207-215.

Arnold, J. (2011). Attention to affect in language learning. Anglistik. International Journal of English Studies, 22(1), 11-22.

Aydin, S. (2008). An investigation on the language anxiety and fear of negative evaluation among Turkish EFL learners. Asian EFL Journal, 30 (1), 42 1-444.

Aydin, S., Harputlu, L., Güzel, S., Savran Çelik, Ş., Uştuk, Ö. \& Genç, D. (2016). A Turkish version of Foreign Language Anxiety Scale: Reliability and validity. Procedia Social and Behavioral Sciences, 232, 250-256. DOI: 10.1016/j.sbspro.2016.10.011

Campbell, C. M., \& Shaw, V. M. (1994). Language anxiety and gender differences in adult second language learners: Exploring the relationship. In C. A. Klee (Ed.), Face in a crowd: The individual learner in multi section courses (pp. 215- 244). Boston: Heinle \& Heinle.

Chan, D. Y. C., \& Wu, G. C. (2004). A study of foreign language anxiety of EFL elementary school students in Taipei County. Journal of National Taipei Teachers College, 17(2), 287-320.

Coşkun, G., \& Taşgin, A. (2018). An investigation of anxiety and attitudes of university students towards English courses. Journal of Language and Linguistic Studies, 14.(2), 135-153.

Dewaele, J. M., Petrides, K. V., \& Furnham, A. (2008). Effects of trait emotional intelligence and sociobiographical variables on communicative anxiety and foreign language anxiety among adult multilinguals: A review and empirical investigation. Language Learning, 58(4), 911-960.

Dornyei, Z. (2007). Research methods in applied linguistics: Quantitative, qualitative and mixed methodologies. Oxford University Press.

Dörnyei, Z., \& Ryan, S. (2015). The psychology of the language learner revisited. Routledge.

Dörnyei, Z., \& Taguchi, T. (2010). Questionnaires in second language research: Construction, administration, and processing ( $2^{\text {nd }}$ ed.). Routledge.

Ho, R. (2018). Understanding statistics for the social sciences with IBM SPSS. CRC Press. 
Horwitz, E. K. (1986). Preliminary evidence for the reliability and validity of a foreign language anxiety scale. TESOL Quarterly, 20(3), 559-562.

Horwitz, E. K., Horwitz, M. B., \& Cope, J. (1986). Foreign language classroom anxiety. Modern Language Journal, 7O(2), 125-132.

Hussain, M. A., Shahid, S., \& Zaman, A. (2011). Anxiety and attitude of secondary school students towards foreign language learning. Procedia-Social and Behavioral Sciences, 29, 583-590.

Karagöl, İ., \& Başbay, A. (2018). The relationship among attitude, anxiety, and English speaking performance. Journal of Theoretical Educational Science, 11(4), 809-821.

Kunt, N. (1997). Anxiety and beliefs about language learning: A study of Turkish speaking university students learning English in North Cyprus [Unpublished doctoral dissertation]. University of Texas at Austin.

MacIntyre, P. D. (1999). Language anxiety: A review of the research for language teachers. In D.J. Young (Ed..), Affect in foreign language and second language learning: A practical guide to creating a low-anxiety classroom atmosphere (pp.24-45). New York: McGraw Hill

MacIntyre, P. D., \& Gardner, R. C. (1991). Methods and results in the study of anxiety and language learning: A review of the literature. Language Learning, 41(1), 85117.

MacIntyre, P. D., \& Gardner, R. C. (1994). The subtle effects of language anxiety on cognitive processing in the second language. Language Learning, 44(2), 283-305.

Na, Z. (2007). A study of high school students' English learning anxiety. The Asian EFL Journal, 9(3), 22-34.

Ni, H. (2012). The effects of affective factors in SLA and pedagogical implications. Theory \& Practice in Language Studies, 2(7), 1508-1513.

Oktay, A. (2015). Foreign language teaching: A problem in Turkish education. ProcediaSocial and Behavioral Sciences, 174(1), 584-593.

Öztürk, G., \& Gürbüz, N. (2013). The impact of gender on foreign language speaking anxiety and motivation. Procedia-Social and Behavioral Sciences, 70, 654-665.

Pan, V. L., \& Akay, C. (2015). Ĕ̆itim fakültesinde yabanci dil dersi alan öğrencileri yabanci dil dersine yönelik tutumlarinin ve sinif kaygilarinin incelenmesi. Electronic Journal of Social Sciences, 14(55),79-97.

Spielberger, C. D. (1976). The nature and measurement of anxiety. In Spielberger, C. D. \& Diaz-Guerrero, R. (Eds.), Cross-cultural anxiety (pp. 3-12). Washington, DC: Hemisphere Publishing Corporation.

Spielberger, C. (1983). The Handbook of the State-Trait Anxiety Inventory. Palo Alto, CA.

Tokur, B. (2016). Anadolu lisesi öğrencilerinin yabanci dil kaygilarinin incelenmesi [Unpublished Master's thesis]. Dicle University.

Tuncer, M., Berkant, H. G., Doğan. (2015). İngilizceye yönelik tutum ölçeği'nin Türkçe'ye uyarlanmasi, Journal of Research in Education and Teaching,4(2), 260266.

Unal, M., \& Ilhan, E. (2017). A case study on the problems and suggestions in foreign language teaching and learning at higher education. Journal of Education and Training Studies, 5(6), 64-72.

Wang, M. (2014). An empirical study on foreign language anxiety of non-English major students: Take the sophomores in Inner Mongolia University of Technology as an Example. Studies in Literature and Language, 9(3), 128-135. 


\section{About the Authors}

Zekiye Özer is an assistant professor at Niğde Ömer Halisdemir University, English Language Teaching Department. She earned his MA and $\mathrm{PhD}$ degrees at Hacettepe University. Her areas of interests include individual differences, emotion, positive psychology in SLA.

Ramazan Tetkin is a TEFL researcher and a $\mathrm{PhD}$ candidate at Hacettepe University Foreign Language Teaching Department. He has performed Assistant Editor role in Eurasian Journal of Applied Linguistics for more than two years and currently holding Language Editor role in Hacettepe University Journal of Education. His papers were published in high quality journals. His works mainly focuses on TEFL, educational psychology and educational evaluation. 